American Journal of Environmental Sciences 7 (3): 183-194, 2011

ISSN 1553-345X

(C) 2011 Science Publications

\title{
Escherichia Coli and Biophysicochemical Relationships of Seawater and Water Pollution Index in the Jakarta Bay
}

\author{
${ }^{1,2}$ Endan Suwandana, ${ }^{1}$ Kensuke Kawamura, \\ ${ }^{1}$ Kazuhiko Tanaka, ${ }^{3}$ Yuji Sakuno and ${ }^{4}$ Prihatma Raharjo \\ ${ }^{1}$ Graduate School for International Development and Cooperation, Hiroshima University, \\ 1-5-1 Kagamiyama, Higashihiroshima, Hiroshima 739-8529, Japan \\ ${ }^{2}$ Marine and Fisheries Office of Banten Province, \\ KP3B - Jalan Syeh Nawawi Al Bantani, Palima, Serang, Indonesia \\ ${ }^{3}$ Graduate School of Engineering, Hiroshima University, \\ 1-4-1 Kagamiyama, Higashihiroshimashi, Hiroshima 739-8527, Japan \\ ${ }^{4}$ Jakarta Environmental Management Board (BPLHD), Jl. Casablanca Kav. 1, \\ Kuningan, Jakarta, Indonesia
}

\begin{abstract}
Problem statement: Relationships between Escherichia coli (E. coli) and biophysicochemical properties of seawater at different seasons and water pollution index were investigated in the Jakarta Bay, Indonesia. Approach: Water quality data taken at different seasons (Early Rainy Season (ERS) in November 2007 and Late Dry Season (LDS) in August 2008) were analyzed. Additionally, to compare pollution level at different seasons, Nemerow-Sumitomo Water Pollution Index (WPI) was used. Results: Significant correlation of E. coli occured with only few parameters in the ERS, but with more parameters in the LDS. This might be due to the rainfall intensity in the ERS that was potential to dilute seawater and reduce concentration of some parameters, especially along the offshore stations. However, at the same time, the freshwater coming from land had capacity to force out the polluted water in 13 river systems flowing into the bay; hence it could generate more pollution along the onshore stations. Seawater pollution level slightly increased in the ERS in respect to the addition of polluted water from rivers. In this season, none station was clean, 20 stations were slightly polluted, six stations were moderately polluted and six stations were highly polluted. Meanwhile in the LDS, the number of stations following the above WPI criteria were 9, 16, 3 and 4, respectively, indicating less pollution level. Conclusion/Recommendations: The overall results showed that $E$. coli exhibited significant correlations with more water parameters in the LDS and the WPI showed a little increase in the ERS.
\end{abstract}

Key words: Escherichia coli, biophysicochemical, water pollution index, Jakarta bay, seasonal variations

\section{INTRODUCTION}

Like other metropolitan cities in the world, Jakarta city in Indonesia faces up some environmental problems as an impact of rapid development. Being the country's economic, cultural and political center, Jakarta is targeted by young people to finding jobs and better carrier. The population size of Jakarta almost tripled since the last five decades from 2.9 million in 1961-9.5 million in 2010, based on the tabulation of 2010 National Census.

Rapid development of Jakarta city especially during the centralization period where Indonesian GDP reaching an incredible increase of 5.7 percent per year between 1980 and 1992 (World Resources Institute, 1996) has made Jakarta city growing very fast. With such an economic growth, Jakarta embodies many of the contradictory forces at play in rapidly industrializing megacities of the world. Of course this "engines of growth" can play a vital role in economic development, however at the same time; worsening environmental problems may threaten economic prosperity and human health (World Resources Institute, 1996).

Some issues, such as air and water pollution (Sato and Harada, 2004; World Resources Institute, 1996)

Corresponding Author: Endan Suwandana, Graduate School for International Development and Cooperation, Hiroshima University, 1-5-1 Kagamiyama, Higashihiroshima, Hiroshima 739-8529, Japan Tel/Fax: +81-82-424-6929 
and urban waste (Steinberg, 2007), are among the impact of environmental aspects being faced by Jakarta Provincial Government. Garbage such as plastics, woods, bottles and other solid wastes are easily found in the canal and river systems, worsening the water quality. The wastes are drifted to the coastal zone of the Jakarta Bay as the final destination. The massive dead of fishes in 2004 in the Jakarta Bay could be an evidence of pollution level in 13 river systems in Jakarta City (Steinberg, 2007).

Jakarta Bay received three important sources of water pollution, i.e., industrial waste, household discharge and solid trash/garbage. The condition is worsened by poor drainage systems and weak law enforcement (Colbran, 2009; Willoughby et al., 1997). William et al. (2000) reported that high concentrations of heavy metals were found in the water column and sediment bed of the Jakarta Bay. This condition threatens the population of some biodiversities in the bay, such as molluscan fauna (Van der Meij et al., 2009). The pollution level also gives impact on the economic loss of the fisheries in the area as described by Anna and Fauzi (2008).

There are numerous water indicators that can be used to evaluate water quality level, including physical, chemical and biological parameters. Each parameter has associations with other environmental attributes, for example salinity with precipitation, turbidity with sedimentation rate, $\mathrm{pH}$ with alkalinity, etc. Among these water parameters, Escherichia coli (E. coli) concentration has been widely used as bioindicator to quantify water quality condition, for example in ground water (UNESCO, 2000) river water (Kido et al., 2009; Yisa and Jimoh, 2010) and seawater (Costa et al., 2000).

$E$. coli is widely known as biological indicator of soil and water pollution. It is one type of fecal coliform bacteria that is commonly found in the intestines of warm-blooded animals and human. Most $E$. coli strains are actually harmless, but some like O157:H7 can cause serious poisoning in human body. Besides human excrements, cattle faeces are among the important sources of this pathogen strain in the environment (Campbell et al., 2001). Like other bacteria, E. coli prefers to live in the water containing high nutrious elements and organic materials; therefore the presence in water is a strong indication of recent sewage or animal waste contamination (Jalal et al., 2010). One important factor that can exacerbate the high presence of $E$. coli in the environment is poor management of city sewage systems (Brussow et al., 1992).

Beside single indicator such as $E$. coli, scientists developed multi-parameter pollution indicators oftenly called Water Quality Index (WQI) and Water Pollution
Index (WPI). Both indices are almost similar in use. WQI is used to evaluate water condition especially for consumable water, while WPI is more applicable for evaluating pollution level of a water ecosystem. WQI/WPI is calculated from several water parameters with a set of equations and circumstances. Terrado et al. (2010) lists about 55 different WQI and WPI introduced by many scientists in the world.

This paper attempts to 1) compare the relationships between $E$. coli concentration and biophysicochemical properties of seawater at different seasons in the Jakarta Bay; and 2) calculate and compare the WPI between offshore and onshore stations at different seasons.

\section{MATERIALS AND METHODS}

Study site: The study site is located in the Jakarta Bay with a total area of $285 \mathrm{~km} 2,33 \mathrm{~km}$ of the coastline and $8.4 \mathrm{~m}$ of the average water depth. There are 13 river systems flowing into the bay with the average water debit of $112.7 \mathrm{~m} 3 \mathrm{sec}-1$. Some human activities like industries, harbors, fishing ports, marine aquaculture, tourisms, slum areas and luxury settlements are located along the coastline. For the purpose of analysis, the stations are divided into offshore stations, i.e., A, B, C and D and onshore stations, i.e., M1 - M9 (Fig. 1).

Data sources: Water quality data of the seawater was derived from the Jakarta Environmental Management Board (BPLHD). Two series of water quality data taken in November 2007, representing early rainy season (ERS) and in August 2008, representing late dry season (LDS), were analyzed. A total of 32 stations were defined throughout the Jakarta Bay, where 30 water parameters, including 5 physical, 20 chemical and 5 biological parameters, were measured in each station, as listed in Table 1.

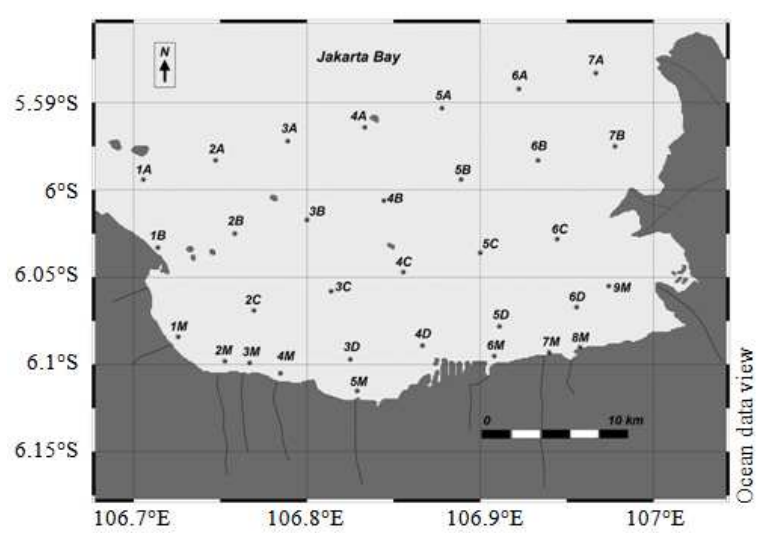

Fig. 1: Distribution of the sampling stations in the Jakarta Bay 
Am. J. Environ. Sci., 7 (3): 183-194, 2011

Table 1: Mean values and standard deviations of the observed water properties and their PVs in the seawater.

\begin{tabular}{|c|c|c|c|c|c|c|c|c|}
\hline & \multirow[b]{3}{*}{ No } & \multirow[b]{3}{*}{ Parameter } & \multirow[b]{3}{*}{ Unit } & \multicolumn{5}{|c|}{ Values (Mean \pm std. dev.) } \\
\hline & & & & \multicolumn{2}{|l|}{ Nov 07} & \multicolumn{2}{|l|}{ Aug 08} & \multirow[b]{2}{*}{$\mathrm{PV} *$} \\
\hline & & & & Offshore & Onshore & Offshore & Onshore & \\
\hline \multirow[t]{5}{*}{ Phys. } & 1 & TDS & $\mathrm{mg} \mathrm{l}^{-1}$ & $3.02 \mathrm{E} 4 \pm 2.05 \mathrm{E} 3$ & $2.22 \mathrm{E} 4 \pm 9.40 \mathrm{E} 3$ & $3.55 \mathrm{E} 4 \pm 5.32 \mathrm{E} 3$ & $2.04 \mathrm{E} 4 \pm 1.06 \mathrm{E} 4$ & - \\
\hline & 2 & TSS & $\mathrm{mg} 1^{-1}$ & $3.22 \pm 1.35$ & $24.89 \pm 17.42$ & $4.61 \pm 2.19$ & $26.33 \pm 20.85$ & 20 \\
\hline & 3 & Turbidity & NTU & $1.26 \pm 1.48$ & $5.67 \pm 1.80$ & $1.87 \pm 1.18$ & $8.50 \pm 7.24$ & 5 \\
\hline & 4 & Temperature & ${ }^{\circ} \mathrm{C}$ & $30.55 \pm 0.44$ & $30.35 \pm 0.81$ & $28.25 \pm 0.32$ & $29.21 \pm 0.69$ & - \\
\hline & 5 & Water transparency & $\mathrm{m}$ & $2.94 \pm 1.58$ & $0.58 \pm 0.36$ & $2.93 \pm 1.05$ & $0.74 \pm 0.66$ & - \\
\hline \multirow[t]{20}{*}{ Chem. } & 6 & Salinity & $\%$ & $32.04 \pm 1.46$ & $27.72 \pm 6.18$ & $31.57 \pm 0.65$ & $29.22 \pm 4.16$ & - \\
\hline & 7 & Ammonia $\left(\mathrm{NH}_{3}\right)$ & $\mathrm{mg} \mathrm{l}^{-1}$ & $0.181 \pm 0.132$ & $2.746 \pm 2.685$ & $0.013 \pm 0.022$ & $1.292 \pm 2.014$ & 0.00 \\
\hline & 8 & $\mathrm{KMnO}_{4}$ & $\mathrm{mg}^{-1}$ & $64.90 \pm 19.22$ & $51.14 \pm 13.21$ & $106.31 \pm 32.75$ & $86.57 \pm 25.71$ & - \\
\hline & 9 & Nitrate $\left(\mathrm{NO}_{3}\right)$ & $\mathrm{mg} \mathrm{l}^{-1}$ & $0.004 \pm 0.019$ & $0.027 \pm 0.080$ & $0.000 \pm 0.000$ & $0.132 \pm 0.112$ & 0.008 \\
\hline & 10 & Disovld. Oxyg. (DO) & $\mathrm{mg} \mathrm{l}^{-1}$ & $7.68 \pm 3.11$ & $2.86 \pm 2.26$ & $5.31 \pm 0.76$ & $3.74 \pm 2.73$ & 5 \\
\hline & 11 & Phosphate $\left(\mathrm{PO}_{4}\right)$ & $\mathrm{mg} \mathrm{l}^{-1}$ & $0.007 \pm 0.018$ & $0.231 \pm 0.234$ & $0.023 \pm 0.028$ & $0.428 \pm 0.466$ & 0.015 \\
\hline & 12 & Phenol & $\mathrm{mg}^{-1}$ & $0.016 \pm 0.005$ & $0.018 \pm 0.004$ & $0.000 \pm 0.002$ & $0.012 \pm 0.004$ & 0.002 \\
\hline & 13 & Sulfide $\left(\mathrm{H}_{2} \mathrm{~S}\right)$ & $\mathrm{mg} \mathrm{l}^{-1}$ & $0.000 \pm 0.000$ & $0.019 \pm 0.031$ & $0.004 \pm 0.008$ & $1.134 \pm 2.941$ & 0.00 \\
\hline & 14 & Oil and Fat & $\mathrm{mg}^{-1}$ & $0.083 \pm 0.105$ & $0.064 \pm 0.030$ & $0.073 \pm 0.052$ & $0.103 \pm 0.182$ & 1.00 \\
\hline & 15 & Blue Methylene & $\operatorname{mg~}^{-1}$ & $0.076 \pm 0.059$ & $0.081 \pm 0.059$ & $0.010 \pm 0.000$ & $0.407 \pm 0.638$ & 0.001 \\
\hline & 16 & COD & $\operatorname{mg~}^{-1}$ & $102.4 \pm 14.94$ & $76.57 \pm 13.20$ & $33.76 \pm 13.06$ & $121.25 \pm 37.14$ & - \\
\hline & 17 & $\mathrm{BOD}$ at $20^{\circ} \mathrm{C} 5$ days & $\mathrm{mg}^{-1}$ & $29.20 \pm 8.45$ & $31.05 \pm 10.73$ & $0.152 \pm 0.05$ & $34.20 \pm 6.82$ & 20 \\
\hline & 18 & pH & & $8.11 \pm 0.19$ & $7.67 \pm 0.19$ & $8.60 \pm 0.18$ & $7.83 \pm 0.32$ & $7-8.5$ \\
\hline & 19 & Zink (Zn) & $\operatorname{mg~}^{-1}$ & $0.033 \pm 0.047$ & $0.014 \pm 0.011$ & $0.015 \pm 0.008$ & $0.026 \pm 0.010$ & 0.095 \\
\hline & 20 & Mercury (Hg) & $\operatorname{mg~l}^{-1}$ & $0.00 \pm 0.00$ & $0.00 \pm 0.00$ & $0.00 \pm 0.00$ & $0.00 \pm 0.00$ & 0.002 \\
\hline & 21 & Copper $(\mathrm{Cu})$ & $\mathrm{mg}^{-1}$ & $0.00 \pm 0.00$ & $0.00 \pm 0.00$ & $0.00 \pm 0.00$ & $0.00 \pm 0.00$ & 0.005 \\
\hline & 22 & Lead $(\mathrm{Pb})$ & $\mathrm{mg} \mathrm{l}^{-1}$ & $0.00 \pm 0.00$ & $0.00 \pm 0.00$ & $0.00 \pm 0.00$ & $0.00 \pm 0.00$ & - \\
\hline & 23 & Cadmium (Cd) & $\mathrm{mg}^{-1}$ & $0.00 \pm 0.00$ & $0.00 \pm 0.00$ & $0.00 \pm 0.00$ & $0.00 \pm 0.00$ & 0.002 \\
\hline & 24 & Chromium (Total) & $\mathrm{mg} \mathrm{l}^{-1}$ & $0.00 \pm 0.00$ & $0.00 \pm 0.00$ & $0.00 \pm 0.00$ & $0.00 \pm 0.00$ & 0.002 \\
\hline & 25 & Nickel (Ni) & $\mathrm{mg} \mathrm{l}^{-1}$ & $0.00 \pm 0.00$ & $0.00 \pm 0.00$ & $0.00 \pm 0.00$ & $0.00 \pm 0.00$ & 0.075 \\
\hline \multirow[t]{5}{*}{ Biol. } & 26 & E. coli $(\log )$ & ind $\mathrm{dl}^{-1}$ & $2.447 \pm 1.423$ & $5.388 \pm 1.604$ & $0.512 \pm 0.481$ & $5.239 \pm 2.005$ & $2.30103 * *$ \\
\hline & 27 & Fecal Coliforms (log) & ind/dl & $1.986 \pm 1.400$ & $5.027 \pm 1.678$ & $0.365 \pm 0.348$ & $4.777 \pm 1.540$ & $3.0 * *$ \\
\hline & 28 & Phytoplankton (log) & ind $\mathrm{m}^{-3}$ & $7.04 \pm 0.47$ & $7.94 \pm 0.53$ & $7.84 \pm 0.91$ & $6.35 \pm 0.61$ & - \\
\hline & 29 & Zooplankton $(\log )$ & ind $\mathrm{m}^{-3}$ & $3.34 \pm 0.37$ & $3.94 \pm 0.58$ & $3.16 \pm 0.54$ & $2.42 \pm 0.81$ & - \\
\hline & 30 & Macrobenthos $(\log )$ & ind $\mathrm{m}^{-3}$ & $3.08 \pm 0.67$ & $1.97 \pm 0.40$ & $2.82 \pm 0.79$ & $1.98 \pm 1.29$ & - \\
\hline
\end{tabular}

Note: - * Ministry of Enviroment of Indonesia, regulation no. 51/2004 (for marine biota and tourism); ** in logaritmic format, - The underlined values have exceeded their PVs

Methods: Bivariate correlation and simple regression analysis between $E$. coli concentration and biophysicochemical properties of seawater were performed using SPSS ver. 16.0. Pearson-R correlation and $R$-squared linear coefficients were used to evaluate the magnitude and direction of the association between variables. Two-tailed test with a confidence level $(\alpha)$ of 0.05 and 0.1 was used to examine the significancy of the result. Ocean Data View (ODV) software version 4.2.1 was used to create an interpolation image of water transparency distribution by applying DIVA gridding technique. DIVA gridding has been incorporated in the last version of ODV and generally produces better results than Qucik Gridding in cases of sparse and heterogeneous data coverage and in cases the study area is separated by land masses (small islands), ridges or bathymetric barriers such as Jakarta Bay,

In order to analyze the pollution level of the Jakarta Bay at different seasons, a WPI was calculated from all measured water properties by using Nemerow and Sumitomo (1970) method. This method, one among numerous water quality indices, was used to measure water pollution index in several studies (Karami et al., 2009; Nemerow, 2007; Prakirake et al., 2008; Terrado et al., 2010). The Nemerow-Sumitomo method became formally used for water quality analysis in Indonesia, since it has been included in the regulation of the Ministry of Environment of Indonesia No. 115/2003 regarding Water Quality Measurement Guideline; therefore it was used in this study.

The function of this method was to standardize the concentrations of all water parameters such that the different concentration ranges for each water parameter were rescaled by the equation to produce a relative value that lies within a comparable range. The WPI is a function of relative values $\left(\mathrm{C}_{\mathrm{i}} / \mathrm{L}_{\mathrm{i}}\right)$, where $\mathrm{C}_{\mathrm{i}}$ represents the concentration of parameter $i$ and $\mathrm{L}_{\mathrm{i}}$ represents the $\mathrm{PV}$ of parameter i defined by a regulation: 
Am. J. Environ. Sci., 7 (3): 183-194, 2011

WPI $=$ a function of $\left(\mathrm{C}_{\mathrm{i}} / \mathrm{L}_{\mathrm{i}}\right)^{\prime} \mathrm{s}$

$=\mathrm{f}\left(\mathrm{C}_{1} / \mathrm{L}_{1}, \mathrm{C}_{2} / \mathrm{L}_{2}, \mathrm{C}_{3} / \mathrm{L}_{3}, \ldots \mathrm{C}_{\mathrm{n}} / \mathrm{L}_{\mathrm{n}}\right)$

(i $=1,2,3, \ldots, n)$

Then, the WPI for a specific water use $\mathrm{j}\left(\mathrm{WPI}_{\mathrm{j}}\right)$ is further expressed by the following equation:

$$
\text { WPI }_{j}=\sum_{\mathrm{i}=1}^{\mathrm{n}} \sqrt{\frac{\left(\mathrm{C}_{\mathrm{i}} / \mathrm{L}_{\mathrm{ij}}\right)_{\max }^{2}+\left(\mathrm{C}_{\mathrm{i}} / \mathrm{L}_{\mathrm{ij}}\right)_{\text {ave }}^{2}}{2}}
$$

where, $C_{i}$ is the measured concentration of parameter $i$, $L_{i j}$ is the PV for parameter i determined for water use $j$, and $\left(\mathrm{C}_{\mathrm{i}} / \mathrm{L}_{\mathrm{ij}}\right)_{\max }$ and $\left(\mathrm{C}_{\mathrm{i}} / \mathrm{L}_{\mathrm{ij}}\right)_{\mathrm{ave}}$ are maximum and average values of $\mathrm{C}_{\mathrm{i}} / \mathrm{L}_{\mathrm{ij}}$ for water use $\mathrm{j}$, respectively.

For the water parameters for which the higher value represents a higher level of pollution, such as nitrate and heavy metals, the values of $\mathrm{C}_{\mathrm{i}} / \mathrm{L}_{\mathrm{ij}}$ obtained from field measurements can be directly calculated using the above equation, with a prerequisite. The prerequisite is that if the value of $\mathrm{C}_{\mathrm{i}} / \mathrm{L}_{\mathrm{ij}}$ obtained from the measurement is greater than 1.0 , then the $\mathrm{C}_{\mathrm{i}} / \mathrm{L}_{\mathrm{ij}}$ value must be standardized by applying the following equation:

$\left(\mathrm{C}_{\mathrm{i}} / \mathrm{L}_{\mathrm{ij}}\right)_{\text {new }}=1.0+\mathrm{k} \times \log \left(\mathrm{C}_{\mathrm{i}} / \mathrm{L}_{\mathrm{ij}}\right)_{\text {ave }}$

where, $\mathrm{k}$ is the free constant (usually 5).

For the parameters where the lower value represents a higher level of pollution, such as Dissolved Oxygen (DO), the $\mathrm{C}_{\mathrm{i}} / \mathrm{L}_{\mathrm{ij}}$ values obtained from field measurements must be standardized by using the following equation:

$\left(C_{i} / L_{i j}\right)_{n e w}=\frac{C_{i m}-C_{i}}{C_{i m}-L_{i j}}$

where, $\mathrm{C}_{\mathrm{im}}$ is the saturation value for any parameter at room temperature (e.g., for $\mathrm{DO}, C_{i m}$ at $25^{\circ} \mathrm{C}$ is 7).

For parameters for which the $\mathrm{PV}\left(\mathrm{L}_{\mathrm{ij}}\right)$ is defined by a range of numbers, such as for $\mathrm{pH}$, where the $\mathrm{PV}$ ranges from 6 to 8.5, a standardized value of $\mathrm{C}_{\mathrm{i}} / \mathrm{L}_{\mathrm{ij}}$ is required, which is calculated by the following equation.

If $\mathrm{C}_{\mathrm{i}} \leq$ average $\mathrm{L}_{\mathrm{ij}}$ :

$\left(C_{\mathrm{i}} / \mathrm{L}_{\mathrm{ij}}\right)_{\text {new }}=\frac{\mathrm{C}_{\mathrm{i}}-\left(\mathrm{L}_{\mathrm{ij}}\right)_{\text {ave }}}{\left(\mathrm{L}_{\mathrm{ij}}\right)_{\min }-\left(\mathrm{L}_{\mathrm{ij}}\right)_{\text {ave }}}$

$$
\text { If } \mathrm{C}_{\mathrm{i}}>\text { average } \mathrm{L}_{\mathrm{ij}} \text { : }
$$

$$
\left(C_{\mathrm{i}} / \mathrm{L}_{\mathrm{ij}}\right)_{\text {new }}=\frac{\mathrm{C}_{\mathrm{i}}-\left(\mathrm{L}_{\mathrm{ij}}\right)_{\text {ave }}}{\left(\mathrm{L}_{\mathrm{ij}}\right)_{\max }-\left(\mathrm{L}_{\mathrm{ij}}\right)_{\text {ave }}}
$$

where, $\left(\mathrm{L}_{\mathrm{ij}}\right)_{\min }$ and $\left(\mathrm{L}_{\mathrm{ij}}\right)_{\max }$ are, respectively, the minimum and maximum values of $\mathrm{L}_{\mathrm{ij}}$ (e.g., $\mathrm{pH}$ : $\min =$ 6 , $\max =8.5)$. The $\left(\mathrm{L}_{\mathrm{ij}}\right)_{\mathrm{ave}}$ is the average value of $\mathrm{L}_{\mathrm{ij}}$ (e.g., $\mathrm{pH}:(6+8.5) / 2=7.25)$.

The pollution level is determined in four criteria as classified by the following definitions:

$0.0 \leq \mathrm{PI} \leq 1.0 \quad=$ Clean $(\mathrm{C})$

$1.0<\mathrm{PI} \leq 5.0 \quad=$ Slightly Polluted $(\mathrm{SP})$

$5.0<\mathrm{PI} \leq 10 \quad=$ Moderately Polluted $(\mathrm{MP})$

$\mathrm{PI}>10 \quad=$ Highly Polluted $(\mathrm{HP})$

According to the above equations, NemerowSumitomo WPI needs a set of PV for each parameter as an input for the equation and this PV is likely to be designed by a government regulation. Table 1 lists the mean value and standard deviation of all measured parameters along with their PVs in seawater designated by the regulation of Ministry of Environment of Indonesia no. 51/2004. This regulation is designed for the purpose of marine tourism activities and marine living organism. Although in total 30 water properties have been measured in the ERS and LDS, but only the parameters having designated PVs were inputted in the WPI equations (Table 1). Some parameters such as TDS, temperature, salinity, were excluded from WPI calculation, because their PVs are not defined by the regulation.

\section{RESULTS}

Biophysicochemical properties of seawater at different seasons: For comparison, the sampling stations were divided into offshore (23 stations) and onshore (9 stations) area (Fig. 1). In general, the mean value of biophysicochemical water parameters in the onshore area was several times higher (in case of Dissolved Oxygen [DO], lower) than the mean value of water parameters in the offshore area, both in early rainy and late dry season. In the onshore area, 12 parameters have exceeded the PVs in both seasons, i.e., Total Suspended Solid (TSS), turbidity, ammonia, nitrate, DO, phosphate, phenol, sulfide, blue methylene, Biological Oxygen Demand (BOD), E. coli and fecal coliforms. Meanwhile in the offshore area, only five parameters in both seasons have exceeded the PVs (Table 1 and Fig. 2). 
Am. J. Environ. Sci., 7 (3): 183-194, 2011
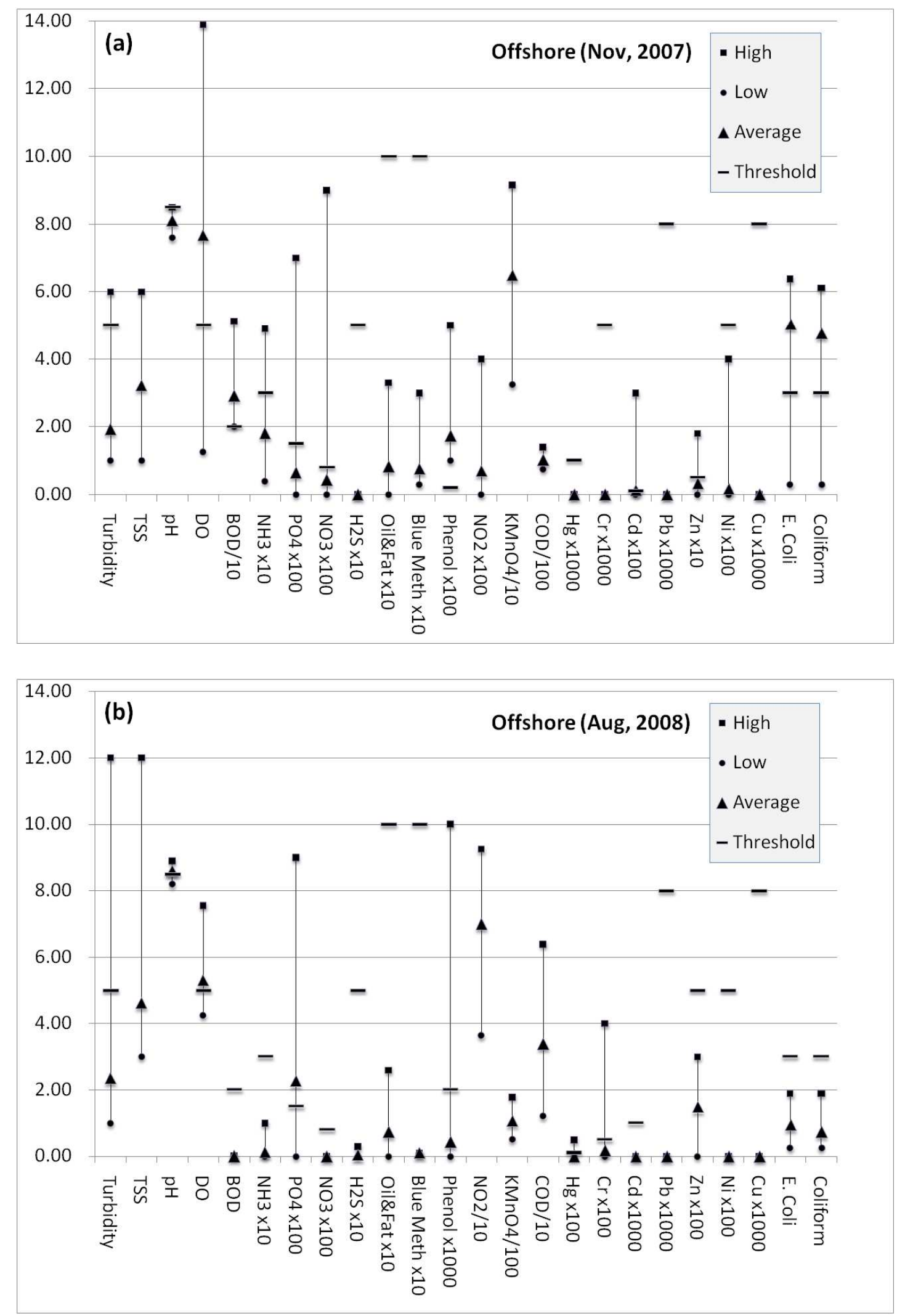
Am. J. Environ. Sci., 7 (3): 183-194, 2011
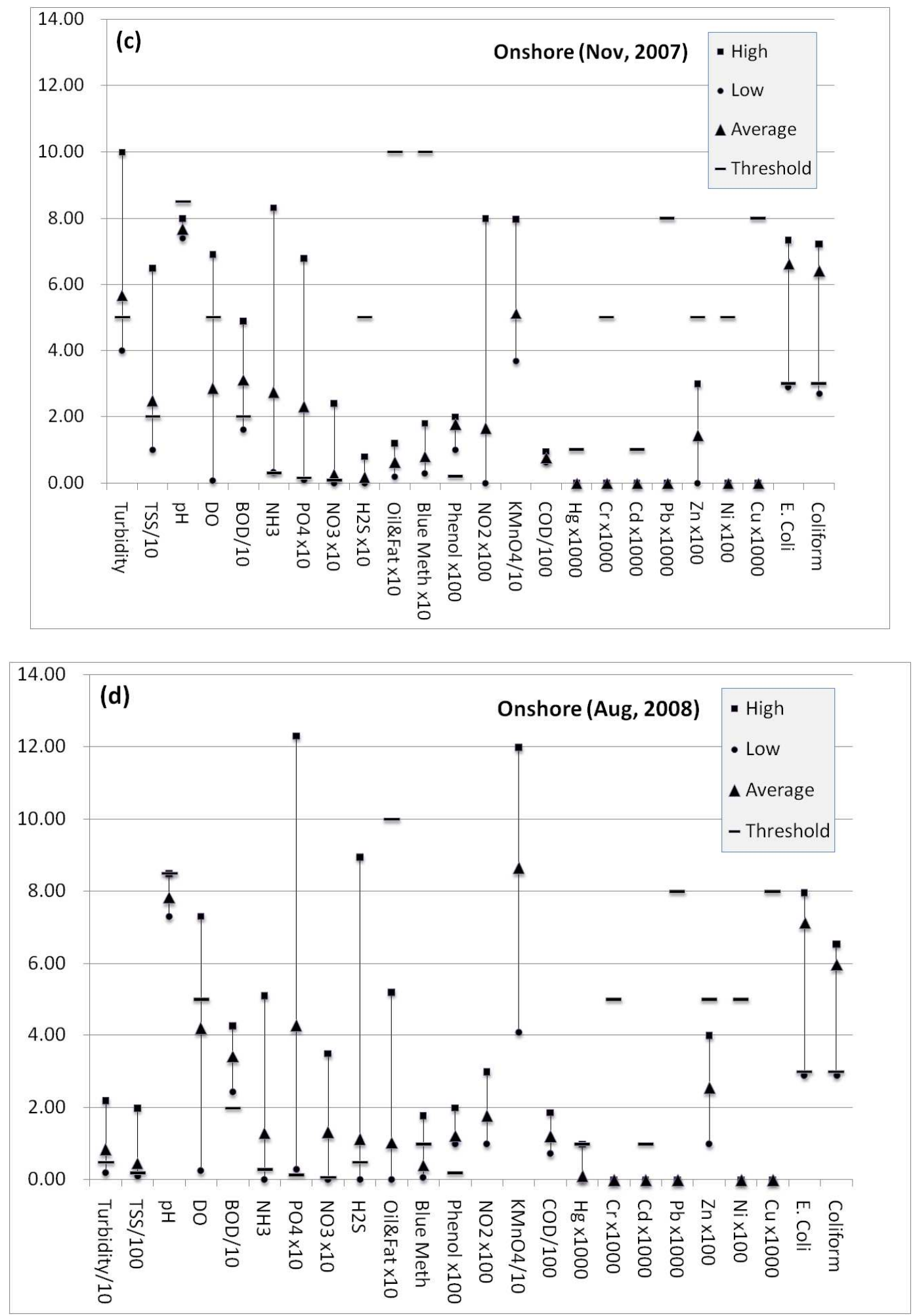

Fig. 2: The standardized PV, minimum, maximum and average values of water parameters in the offshore and onshore stations at different seasons 
Am. J. Environ. Sci., 7 (3): 183-194, 2011
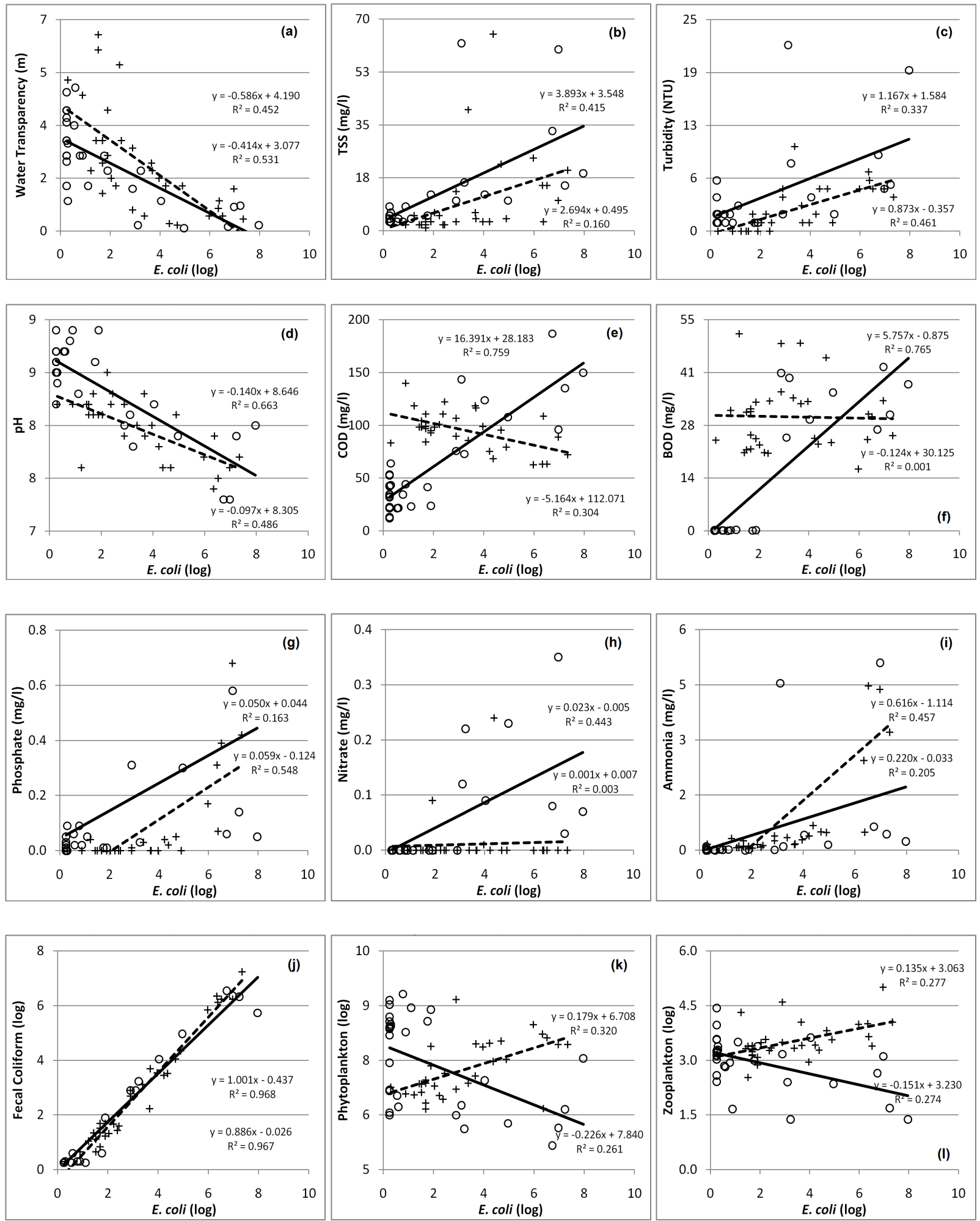

Fig. 3: Relationships between E. coli and some physical $(\mathrm{a}-\mathrm{c})$, chemical $(\mathrm{d}-\mathrm{i})$ and biological $(\mathrm{j}-1)$ properties of seawater at the ERS (+ / ---) and $\operatorname{LDS}(\circ /-)$ 
Am. J. Environ. Sci., 7 (3): 183-194, 2011

Table 2: Regression and correlation coefficients between $E$. coli concentration and other water parameters

\begin{tabular}{|c|c|c|c|c|c|c|c|c|c|c|c|c|c|c|}
\hline & & \multicolumn{4}{|l|}{ Physical } & \multicolumn{5}{|l|}{ Chemical } & \multicolumn{4}{|l|}{ Biological } \\
\hline & & Transp & Turbid & TSS & $\mathrm{pH}$ & Cod & Bod & $\mathrm{PO}_{4}$ & $\mathrm{NH}_{3}$ & $\mathrm{NO}_{3}$ & Coliforms & Phyto & Zoopl & WPI \\
\hline E. coli & $\mathrm{r}$ & $72 * *$ & $-0.679 * *$ & $0.399 *$ & $-0.697 *$ & $-0.551 * *$ & .027 & $740 * *$ & $676 * *$ & 0.054 & & & & $605 * *$ \\
\hline (Nov, & Sig & 0.000 & 0.000 & 0.024 & 0.000 & 0.001 & 0.883 & 0.000 & 0.000 & 0.768 & 0.000 & 0.001 & 0.002 & 0.000 \\
\hline 2007) & $r^{2}$ & & 0.461 & 0.160 & 0.486 & & & & & & & & & \\
\hline E. coli & $\mathrm{r}$ & $-0.729 * *$ & $0.581 * *$ & $0.644 * *$ & $-0.814 * *$ & $0.871 * *$ & $0.875^{* *}$ & $0.404 *$ & $0.453 * *$ & $0.665^{* *}$ & $0.983 * *$ & $-0.511 * *$ & $-0.523 * *$ & $0.942 * *$ \\
\hline (Aug, & Sig & 0.000 & 0.000 & 0.000 & 0.000 & 0.000 & 0.000 & 0.022 & 0.009 & 0.000 & 0.000 & 0.003 & 0.002 & 0.000 \\
\hline 2008) & & 0.531 & 0.337 & 0.415 & 0.663 & 0.759 & 0.765 & 0.163 & 0.205 & 0.443 & 0.967 & 0.261 & 0.274 & 0.886 \\
\hline
\end{tabular}

Table 3: Results of WPI in the offshore and onshore stations at different seasons

\begin{tabular}{lllllr}
\hline & \multicolumn{2}{l}{$\begin{array}{l}\text { Early rainy season Nov 2007 } \\
\text { Number of station }\end{array}$} & & \multicolumn{2}{l}{$\begin{array}{l}\text { Late dry season Aug 2008 } \\
\text { Number of station }\end{array}$} \\
& Offshore & Onshore & Total & Offshore & Onshore \\
\hline Criteria & 0 & 0 & 0 & 9 & 0 \\
Clean (C) & 18 & 2 & 20 & 14 & 2 \\
Slightly Polluted (SP) & 4 & 2 & 6 & 0 & 3 \\
Moderately Polluted (MP) & 1 & 5 & 6 & 0 & 4 \\
Highly Polluted (HP) & 23 & 9 & 32 & 23 & 9 \\
Total & & &
\end{tabular}

Relationships between $E$. coli and water parameters: In this study, we focused on E. coli concentration and its relation to physical, chemical and biological properties of seawater (Fig. 3). Table 2 summarizes the results of bivariate correlation and simple regression analysis between $E$. coli and other water parameters at different seasons in the Jakarta Bay.

Water Pollution Index: Table 3 summarized number of stations in the offshore and onshore stations in both seasons that were classified based on the WPI criteria. The results indicate that most of the sampling stations fall within SP criteria with 20 stations $(62.5 \%)$ in the ERS and 16 stations (50\%) in the LDS. Overall, the water tended to be more polluted in the ERS ( $\mathrm{C}=0$, SP $=20, \mathrm{MP}=6$ and $\mathrm{HP}=6)$ compared to that of in the $\operatorname{LDS}(\mathrm{C}=9, \mathrm{SP}=16, \mathrm{MP}=3$, and $\mathrm{HP}=4)$.

\section{DISCUSSION}

Biophysicochemical properties of seawater at different seasons: In respect to seasonal variability, water parameters were responsive to precipitation. For example, in the ERS, although rainfall intensity in this period was not as much as in mid rainy season (Fig. 4), but the presence of rainwater in this period was sufficient to slightly dilute seawater as can be observed from most of water parameters. Therefore some parameters showed relatively lower mean values than those of in the LDS, especially in the onshore area, for example turbidity, potassium permanganate $\left(\mathrm{KMnO}_{4}\right)$, nitrate, salinity, phosphate, sulfide, blue methylene, TSS, Chemical Oxygen Demand (COD) and BOD.

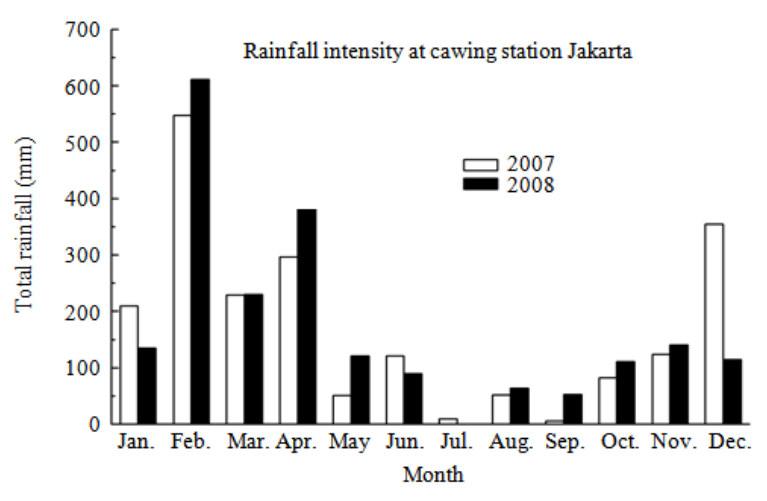

Fig. 4: Monthly changes of precipitation $(\mathrm{mm})$ during 2007 and 2008 at the Cawang rainfall gauge, Jakarta (Suwandana et al., 2011)

However, at the same time, rainfall intensity has also capacity to force out the polluted river water flowing into the bay. Therefore few parameters also showed higher values, i.e. ammonia, phenol, DO, E. coli and fecal coliforms. The resultant of water current from rivers that meets with the waves from open sea could also be the explanatory why the polluted water was more concentrated in the coastal area.

Relationships between $\boldsymbol{E}$ coli and water parameter: From five physical parameters, three parameters showed moderate correlation, i.e., water transparency, TSS and turbidity, both in the ERS and LDS. These parameters are associated with sedimentation rate in the water. Suspended solid in the water body provides suitable media for bacterial microorganisms, such as coliforms, to grow (Narkis et al., 1995). Relationship between $E$. coli and turbidity is also essential especially 
for the raw material of drinking water, where the median of turbidity should be below 0.1 NTU (Nephelometric Turbidity Unit) (Allen et al., 2008).

The impact of rainwater to the physical parameters can be observed from Fig. 3a-c where the value of each parameter, in general, was lower than that of the LDS. Temperature did not show strong correlation with $E$. coli (not shown in Table 2) because there was not significant difference in temperature between ERS and LDS.

Among the chemical parameters, $\mathrm{pH}$ exhibited a very strong correlation with $E$. coli in both seasons. Such strong negative correlation indicated that $E$. coli preferred to grow in a normal to an acidic environment. A laboratory experiment done by Jordan et al. (1999) proved that $E$. coli concentration was very high at $\mathrm{pH}$ 3.0 after 24-h incubation, and even some survivals could still be found after 3-days of experiment.

Among oxygen-related parameters like DO, BOD and COD, two parameters, i.e. COD and BOD, showed high positive correlation with $E$. coli in the LDS. COD is a very important indicator for $E$. coli growth as it measures the capacity of water to consume oxygen during the decomposition of organic matter and the oxidation of inorganic chemicals such as ammonia and nitrate. BOD also showed a strong positive correlation with $E$. coli. Figure $3 \mathrm{e}$ and $\mathrm{f}$ show that BOD and COD concentrations in the LDS were linearly correlated. However, in the ERS, the relationship between $E$. coli and BOD/COD was not so clear. The relationship between COD and BOD is actually not necessarily to be linear in nature. However, the study done by Jin et al. (2009) concluded that in the water containing relatively high concentration of sewage contamination, a linear correlation could exist.

The relationships between $E$. coli and other chemical parameters like phosphate, nitrate and ammonia exhibited from low to moderate correlations based on pearson-r coefficients as presented in Table 2. The correlation of these parameters was not clearly understood and the role of rainwater to these parameters was not clear either. Suppostedly, E. coli should have a strong linear relationship with those three elements. The presence of high organic matter and nutrients, such as phosphorus and nitrites in the seawater can increase the bacterial colony, e.g., E. coli, as reported by Jalal et al. (2010) and Gauthier et al. (1993). Therefore, more field surveys are required, especially in the extreme conditions like in mid rainy and mid dry season, in order to get more precise data.

Beside physicochemical parameters, which their contibution is very important in creating a suitable enviroment for $E$. coli growth, some biological parameters were also analyzed in this study. There were three biological indicators measured during the survey, i.e., fecal coliforms, phytoplankton and zooplankton. The results revealed that $E$. coli showed strong correlations with fecal coliforms in both seasons $\left(\mathrm{R}^{2}=\right.$ $0.967-0.968, \mathrm{P}<0.001)$, because in fact $E$. coli is one type of fecal coliforms. The environmental conditions which are suitable for $E$. coli growth are also suitable for other fecal coliform bacteria, hence the relationship between those two bioindicators was nearly perfect (see Fig. 3j. On the contrary, the relationship with macrobenthos was insignificant. As organisms living on sediment, macrobenthos is not easily influenced by the changes in the seawater properties.

An interesting fact can be observed in the phytoplankton and zooplankton relationships to E. coli. In the LDS, though the correlation coefficient was only 0.261 for phytoplankton and 0.274 for zooplankton, but the trend line was able to describe their association in nature. The negative linears shown in see Fig. $3 \mathrm{k}$ and (1) explain that the more the water got polluted, the less the number of phytoplankton and zooplankton was found. A study done by Fachrul and Syach (2006) in the Jakarta Bay reported that biodiversity index of phytoplankton in the polluted area was around 0.26 , similarity index was close to 0 , and dominance index is nearly 1 , meaning that only one species was dominating the polluted area.

Different situation occured in the ERS, where a positive correlation occurred both for phytoplankton and zooplankton. The average concentration of phytoplankton in the onshore area was higher $(\overline{\mathrm{x}}=7.94$ $\pm \sigma=0.53)$ compared to the one in the offshore area $(\bar{x}$ $=7.04 \pm \sigma=0.47)$. The same situation was performed by zooplankton, where the average concentration was $\overline{\mathrm{x}}$ $=3.94 \pm \sigma=0.58$ for the onshore and $\bar{x}=3.34 \pm \sigma=$ 0.37 for the offshore area.

The reason for high concentration of phytoplankton and zooplankton found in the onshore area during the ERS could be related with the occurrence of high precipitation. Rainfall intensity and nutrients upload from land and river systems might have triggered phytoplankton to start multiplying their population. Within this period, upwelling often occurs, nutrient enrichment takes place and sometimes this may lead to the alga bloom phenomenon (Sellner et al., 2003). Many studies have reported that, with this kind of circumstances, phytoplankton, and then followed by zooplankton, is very sensitive to the increase of nutrient elements introduced by rainwater (Sellner et al., 2003; Lee et al., 2009) and the growth of some phytoplankton species respond very quickly to the rainfall (AlHomaidan and Arif, 1998). 


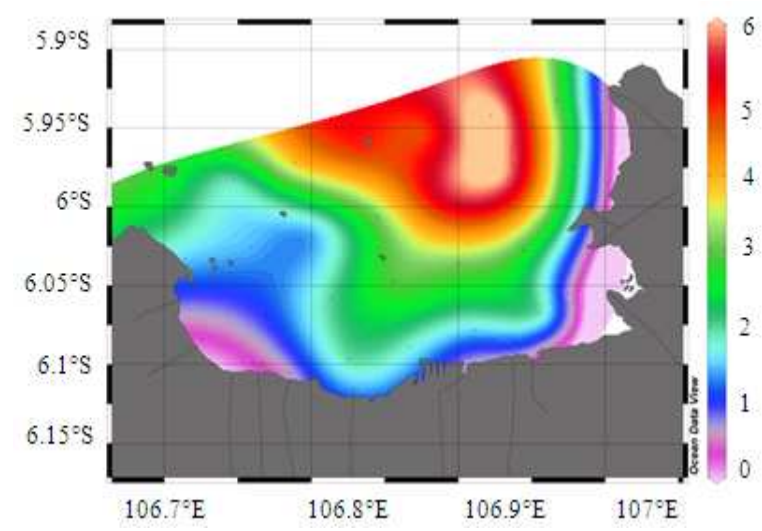

(a)

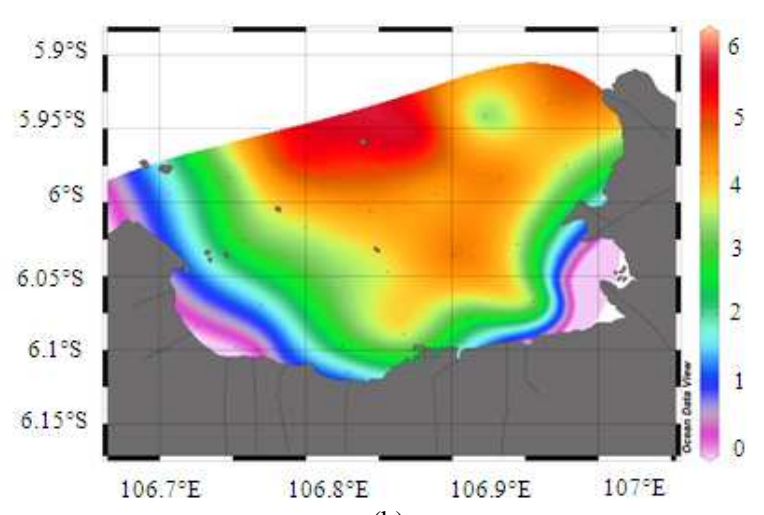

(b)

Fig. 5: Interpolated-water transparency distribution data in the (a) ERS and in the (b) LDS

Water pollution Index: Although E. coli concentration in water column can itself be used as indicator for pollution level, scientists developed numerous water quality indices calculated from multi-parameters of water properties. Instead of relying only on a single pollution indicator, these WPI can better explain the association of whole water properties because all parameters are incorporated in the calculation.

Although, in general the average value of water parameters in the ERS was lower compared to that of in the LDS, but in some stations the concentration was very high due to the influence of water input from river systems, producing high WPI on those stations. This was the reason why, to some extents, it was necessary to conduct a multiple-parameter pollution index, instead of depending only on one pollution indicator such as $E$ coli. According to Terrado et al. (2010), the presence or absent of certain organisms in water, which is used as a single bioindicator, has been introduced since 1848 in Germany, but sometimes it is not sufficient because it does not take into account other toxicological effects nor contaminant substances.
The results of this study could not answer clearly why the WPI in the ERS was more polluted compared to that of in the LDS. However, the supply of rainwater, which started to increase in November 2007 as the onset of the rainy season, could be one reason, because rainwater supply was able to force out the polluted water in 13 river systems flowing into the bay. Some literatures reported that most of the river systems in Jakarta have been classified into highly polluted (Colbran, 2009; Steinberg, 2007; UNESCO, 2000). Therefore, the existence of sufficient rainwater in this period could be an explanatory for the increase of water pollution in the Jakarta Bay.

Unfortunately, the amount of water debit from all river systems in the ERS was unknown; hence it was difficult to statistically measure the impact of rainfall intensity to the increase of water pollution in the bay. However, an attempt was made to overcome this situation by creating a water transparency distribution map from the water transparency point data using DIVA gridding interpolation method (Fig. 5). The water transparency point data was measured by using secchi disk, where the deeper the secchi disk can be visually seen from the water surface, the more transparently (clearer) the seawater is.

It is clearly seen from Fig. 5, there is a significant supply of fresh water from river systems in the ERS (Fig. 5a), as shown by the expansion of purple and blue colors over green and orange colors. The water transparency in this season was more turbid especially in the onshore area $(\overline{\mathrm{x}}=0.58 \pm \sigma=0.36)$ compared to that of in the $\operatorname{LDS}(\bar{x}=0.74 \pm \sigma=0.66)$.

\section{CONCLUSION}

Most of the biophysicochemical properties of seawater in the Jakarta Bay had significant correlations with $E$. coli concentration. Some of those parameters were very essential for $E$. coli growth; hence many significant correlations occurred. The concentration of most water parameters can also be differentiated between offshore and onshore area, where high concentration values occurred mostly in the onshore area, evenmore some already exceeded the PVs. The concentration of water properties was also very responsive to precipitation. The freshwater coming from land (river systems) had two important roles in this environment; one was related its potential in diluting seawater and the other one was related to its capacity in forcing the polluted water in the river systems out into the bay.

Most of the WPI in the sampling stations fall within slightly polluted criteria, with $62.5 \%$ and $50 \%$ 
for the ERS and LDS, respectively. More polluted waters were concentrated nearby the onshore area, while the offshore area was relatively cleaner. The results also show that more polluted stations were found in the ERS compared to the LDS. Although, in general, the average value of most parameters reduced during this season, but the capacity of rainwater was able to bring out the polluted river water coming out into the bay, generating more polluted water in the bay.

\section{ACKNOWLEDGEMENT}

The researchers would like to thank BPLHD Jakarta, Indonesia, for providing the primary data of water quality parameters to be analyzed in this study. Special thank is addressed to Prof. Reiner Schlitzer at AWI Bremerhaven Germany for ODV software and also to Global Environmental Leader (GEL) Program of Hiroshima University for invaluable supports during the study.

\section{REFERENCES}

Allen, M., R. Brecher, R. Copes, S. Hrudey and P. Payment, 2008. Turbidity and Microbial Risk in Drinking Water. Ministry of Health Province of British Columbia, pp: 69. http://www.health.gov.b c.ca/protect/pdf/TACsubmitted

Al-Homaidan, A. and I. Arif, 1998. Ecology and bloom-forming algae of a semi-permanent rain-fed pool at Al-Kharj. Sau. Arabia. J Arid Environ., 38: 15-25. DOI: 10.1006/jare.1997.0319

Anna, S. and A. Fauzi, 2008. Economic loss of pollution to fisheries: An economic analysis of the Jakarta Bay fisheries. Am. Fish. Soc. Symp., 49: 265-272. http://pustaka.unpad.ac.id/wp-content/upl ads/2009/05/1_anna.pdf

Brussow, H., H. Rahim and W. Freire, 1992. Epidemiological analysis of serologically determined rotavirus and enterotoxigenic Escherichia coli infections in Ecuadorian children. Am. Soc. Microbiol., 30: 1585-1587. http://jcm.asm.org/cgi/reprint/30/6/1585

Campbell, G.R., J. Prosser, A. Glover and K. Killham, 2001. Detection of Escherichia coli O157:H7 in soil and water using multiplex PCR. J. Applied Microb., 91: 1004-1010. PMID: 11851807

Colbran, N., 2009. Will Jakarta be the next atlantis? Excessive groundwater use resulting from a failing piped water network. Law. Environ. Dev. J., 5: 2037. http://www.lead-journal.org/ content/09018.pdf
Costa, Jr. O.S, Z.M.A.N Leao, M. Nimmo and M.J. Attrill, 2000. Nutrification impacts on coral reefs from Northern Bahia, Brazil. Hydrobiologia, 440: 307-315. DOI: 10.1023/A:1004104118208

Fachrul, M.F. and J.N. Syach, 2006. The effect of water quality disturbances on phytoplankton communities in Jakarta Bay, Indonesia. http://www.balwois.com/balwois/administration/fu 11_paper/ffp-1199.pdf

Gauthier, M.J., G.N. Flatau, R.L. Clement and P.M. Munro, 1993. The loss of culturability by Escherichia coli cells in seawater depends on avaiability of phosphate ions and phosphate transport systems. Microb. Ecol., 26: 29-35. DOI: $10.2307 / 4251307$

Jalal, K.C.A., Y. Kamaruzzaman, A. Fairuz, B. Akbar and S. Shahbudin et al., 2010. Bacterial communities in Kuantan Estuary of Pahang Malaysia. J. Applied Sci., 10: 652-657. DOI: 10.3923/jas.2010.652.657

Jin, X.L., M. Jing, X. Chen, Z.X. Zhuang and X.R. Wang et al., 2009. A study on the relationship between BOD5 and COD in coastal seawater environment with a rapid BOD measurement system. Water Sci. Technol., 60: 3219-3223. PMID: 19955646

Jordan, K.N., L. Oxford and C.P. O'Byrne, 1999. Survival of low-pH stress by Escherichia coli O157:H7: correlation between alterations in the cell envelope and increased acid tolerance. Appl. Environ. Microb., 65: 3048-3055. PMID: 10388702

Karami, B., K.N. Dhumal, M. Golabi and N. Jaafarzadeh, 2009. Optimization the relationship between water quality index and physical and chemical parameters of water in Bamdezh Wetland. Iran. J. Applied Sci., 9: 3900-3905. DOI: 10.3923/jas.2009.3900.3905

Kido. M., Y. Syawal, M.S. Sulastri, T. Hosokawa and S. Tanaka et al., 2009. Comparison of general water quality of rivers in Indonesia and Japan. Environ. Monit. Assess., 156: 317-329. DOI: 10.1007/s1066 1-008-0487-z

Lee, M., B. Kim, Y. Kwon and J. Kim, 2009. Characteristics of the marine environment and algal blooms in Gamak Bay. Fish Sci., 75: 401411. DOI: $10.1007 / \mathrm{s} 12562-009-0056-6$

Narkis, N., R. Armon, R. Offer, F. Orshansky and E. Friedland, 1995. Effect of suspended solids on wastewater disinfection efficiency by chlorine dioxide. Water Res., 29: 227-236. DOI: 10.1016/00 43-1354(94)E0117-O 
Nemerow, N.L. and H. Sumitomo, 1970. Benefits of Water Quality Enhancement. Report No. 16110 DAJ, prepared for the US Protection Agency. December 1970. Syracuse, University, Syracuse, NY, pp. 202. http://nepis.epa.gov/

Nemerow, N.L., 2007. Industrial Waste Treatment: Contemporary Practice and Vision for the Future. 30 Corporate Drive, Suite 400, Burlington, MA 01803, USA., ISBN: 0123724937, pp: 516.

Prakirake, C., P. Chaiprasert and S. Tripetchkul, 2008. Development of specific water quality index for water supply in Thailand. Songkl. J. Sci. Technol., 31: 91-104. http://www.rdoapp.psu.ac.th/html/sjst/ journal/31-1/0125-3395-31-1-91-104.pdf

Sato, N. and H. Harada, 2004. Trends and prospects of water environmental issues in Jakarta. Indo. Envi. Sys. Res., 32: 11-19.

Sellner, K.G., G.J. Doucette and G.J. Kirkpatrick, 2003. Harmful algal blooms: Causes, impacts and detection. J. Ind. Microbiol. Biot., 30: 383-406. DOI: $10.1007 /$ s10295-003-0074-9

Steinberg. F., 2007. Jakarta: Environmental problems and sustainability. Habitat. Inter., 31: 354-365. DOI: 10.1016/j.habitatint.2007.06.002

Suwandana, E., K. Kawamura and E. Soeyanto, 2011. Assessment of the heavy metals and nutrients status in the seawater, sediment and seagrass in Banten Bay, Indonesia and their distributional patterns. J. Fish. Internat., 6: 18-25. DOI: 10.3923/jfish.2011.18.25
Terrado, M., E. Borrel, S. Campos, D. Barcelo and R. Tauler, 2010. Surface-water-quality indices for the analysis of data generated by automated sampling networks. Trends. Anal. Chem., 29: 40-52. DOI: 10.1016/j.trac.2009.10.001

UNESCO, 2000. Reducing megacity impacts on the coastal environment-alternative livelihoods and waste management in Jakarta and the Seribu Islands. Coastal Region and Small Island Papers 6, UNESCO, Paris, pp. 59. http://www.unesco.org/ csi/pub/papers/mega.htm

Van der Meij, S.E.T., R.G. Moolenbeek and B.W. Hoeksema, 2009. Decline of the Jakarta Bay molluscan fauna linked to human impact. Mar. Pollut. Bull., 59: 101-107. DOI: 10.1016/j.marpol bul.2009.02.021

William, T.M., J.G. Rees and D. Setiapermana, 2000. Metals and trace organic compounds in sediments and waters of Jakarta Bay and the Pulau Seribu Complex, Indonesia. Mar. Pollut. Bull., 40: 277285. DOI: 10.1016/S0025-326X(99)00226-X

Willoughby, N.G., H. Sangkoyo and B.O. Lakaseru, 1997. Beach litter: An increasing and changing problem for Indonesia. Mar. Pollut. Bull., 34: 469478. DOI: 10.1016/S0025-326X(96)00141-5

World Resources Institute, 1996. World Resources 1996-97: The Urban Environment. ISBN 0-19521160-X, pp: 365.

Yisa, J. and T. Jimoh, 2010. Analytical Studies on Water Quality Index of River Landzu. Am. J. Applied Sci., 7: 453-458. DOI: 10.3844/ajassp.2010.4 53.458. 